\title{
Students' Attitudes to Cultural and Religious Diversity and Changing Conditions on Labour Market and in Education System
}

\author{
Postoje studentů ke kulturní a náboženské rozmanitosti a \\ měnícím se podmínkám na trhu práce a ve vzdělávacím systému
}

Hanne-Lore Bobáková, Krystyna Heinz

\begin{abstract}
The presented paper deals with the questionnaire survey conducted by means of the Semantic Differential Method in the groups of students studying at School of Business Administration in Karviná, Silesian University in Opava. The research focuses on students' attitudes towards some controversial aspects of the globalized society characterized by migration and plurality trends. The evaluation of the respondents' opinions is especially related to the areas of religious and cultural diversity as well as the education system and its ability to adequately react to the current changes. Students' answers also show their attitudes to the ethnic diversity at a potential workplace and focus on professional intercultural communication and problems that might occur in it. The paper also involves a short comparison of selected responses in the surveys conducted in 2016 and 2020.
\end{abstract}

Key words: globalization, attitudes, culture, diversity, religion, security, communication barriers

\section{Introduction}

Globalization is related not only to economy, but to numerous areas of social and cultural life. Nowadays, we can observe two different attitudes related to diversity. The first one is founded on a strong valorisation of diversity, which is a crucial value in various dimensions related to identity, model of convergence, relationship with the adversary, and models of alternative societies. A decade ago, diversity was perceived as a temporary phenomenon and was expected to give way to conformity and group unity in the time perspective and proclaimed that it was necessary to preserve the differences as they present the strength. However, currently, the attitudes are changing due to social phenomena like especially migration. There are also various opinions related to the fact whether university students are properly prepared for current economic and social changes and their impact on labour market.

The article focuses on gathering data related to students' attitudes to diversity and its consequences applying the questionnaire survey based on the Method of the Semantic Differential. Using the mentioned method allows the assessment of how respondents perceive minds of various entities from a multi-dimensional point of 
view. It has been proved that the Semantic Differential scale is a useful method to assess the dimensions of mind perception (Takahashi, Ban, Asada, 2016).

Nowadays, cultural diversity belongs to ardent topics, therefore numerous publications have focused on this topic in Europe and outside it. A lot of attention is also devoted to the topic from the point of view of education, e.g. Apeltauer (1996) deals with cultural diversity in terms of multilingualism. Another problem related to cultural diversity acceptance is the goal of research conducted by other researches (Dias, 1991; Bade, 2015; Egel a Colombo 2018).

However, a lot of differentiation and specification of research topics has been observed in the last decade. In addition to highlighting the importance of cultural diversity in higher education with reference to its sustainability (Maschwitz, 2018), linguistic and cultural diversity is also examined (Schütte, 2006, 2018). Psychological factors in assessing cultural diversity were addressed by Kenner (2006) who explored cultural diversity from the perspective of the psychosocial structure of personality, which allows to investigate the moral ability of judgment and attitudes.

Discussions on cultural diversity take place in different forms and in different ways. In today's globalizing society, they affect the whole of European society and have an impact on everyday reality. In principle, the study of cultural diversity can be divided into the following areas:

- cultural management and co-operation management of corporate culture (Urbanová, Čermáková and Vostrovská, 2016; Maschwitz, 2018; Mense-Petermann, 2006),

- health care (Heuser, 2019),

- education (Seip, 2006; Egel, Colombo, 2018; Felcmanová, 2018),

- workplace integration practices (Paufler, 2018; Bade, 2015, 2016),

- migration (Kazzazi, 2016).

The goal of the article is to analyse the respondents' opinions related to the areas of religious and cultural diversity as well as the education system and its ability to adequately react to the current changes in the society, to identify the areas that are omitted or underestimated in the syllabi of tertiary education institutions and to incorporate the missing topics into them. Our intention is also to compare our results to the results of the questionnaire survey that is being conducted at a partner university in Slovakia. 


\section{Methods}

The presented paper deals with the questionnaire research conducted by means of the Semantic Differential Method in the group of 145 students studying Tourism at School of Business Administration in Karviná, Silesian University in Opava in the academic year 2019-20, submitting answers to all the questions included in the questionnaire. The research focuses on students' attitudes towards some controversial aspects of the globalized society characterized by migration and plurality trends (Vaštatková, Chval, 2018). The evaluation of the respondents' opinions is especially related to the areas of religious and cultural diversity as well as the education system and its ability to adequately react to the current changes. The acquired date will be analysed within the individual items of the questionnaire and compared to the selected answers from the questionnaire survey conducted in 2016. The data will be presented in the charts.

Data obtained from questionnaires can be analysed in several ways (Vaštatková, Chval, 2018).

1. item-level response analysis,

2. analysis of responses based on global similarity assessment,

3. analysis of responses at the dimension level.

The first method is based on the creation of concept profiles, the second method concerns the matrix of distance, and the third one is the location of terms in the semantic space.

We are inclined to use the first method of data analysis, where the results in the individual items of the questionnaire will be processed into numerical data on the scale ranging from 1-7. The presented text will contain 11 graphs, each corresponding to one semantic profile of the questionnaire.

\section{Results and evaluation}

1. Cultural and religious diversity is connected with 


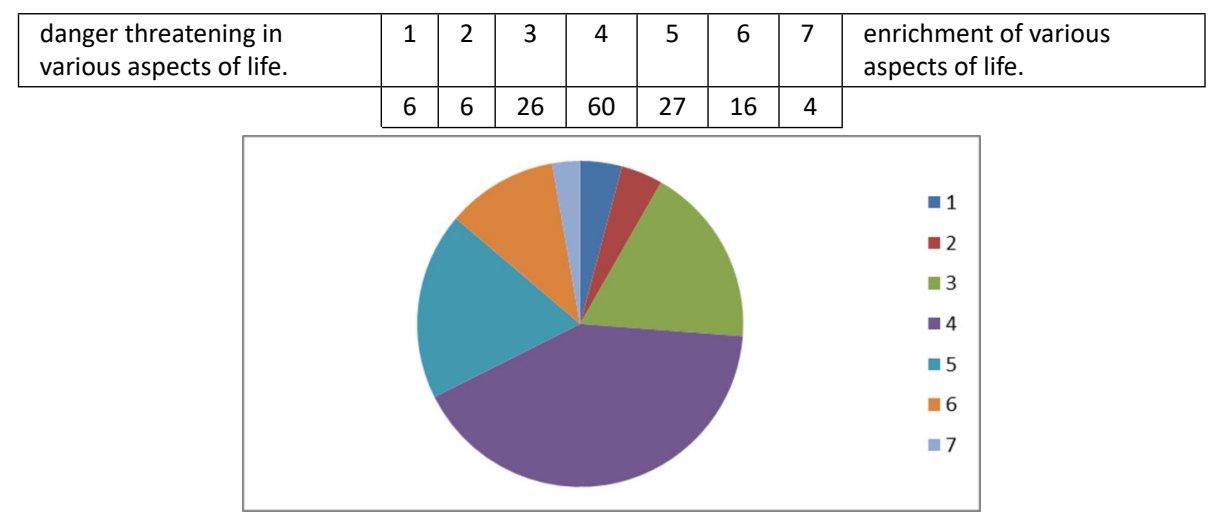

Answering the question 1 about students' attitude to cultural and religious diversity, the majority of students' answers are placed in the middle of the scale within the scale positions $3-5$, which shows that they are not able to determine their position, but a number of students are inclined to see aspects enriching their life in the scale position 5 . At the same time scale positions 1 and 2 indicate that danger connected with diversity is for them of less importance with the number of respondents of 6 in 2 and 6 in the scale position 1, which shows that the respondents are aware of changes taking place in the society and their attitude to them is not negative.

2. Do you prefer the following statement:

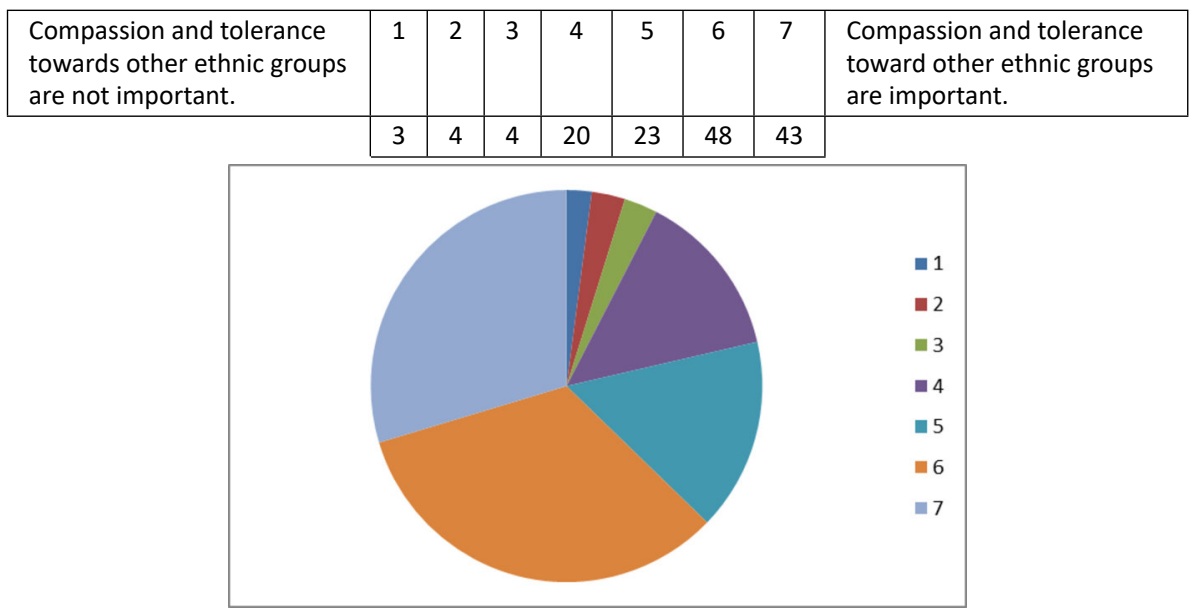

In the answer related to compassion and tolerance students in the question 2 distinctly chose the right side of the offered spectrum stating that compassion 
and tolerance are very important for them - the number of 48 respondents in scale position 6 and the number of 43 in the scale position 7 of the scale, which represents about $62 \%$ answers. Only 7 students think that compassion and tolerance are not important at all in the scale position 1 and 2 and 20 students placed their opinions in the middle of the spectrum. The obtained results have proved that for the respondents compassion and tolerance toward other ethnic groups are definitely important.

3. Do you tend to agree with the concept of

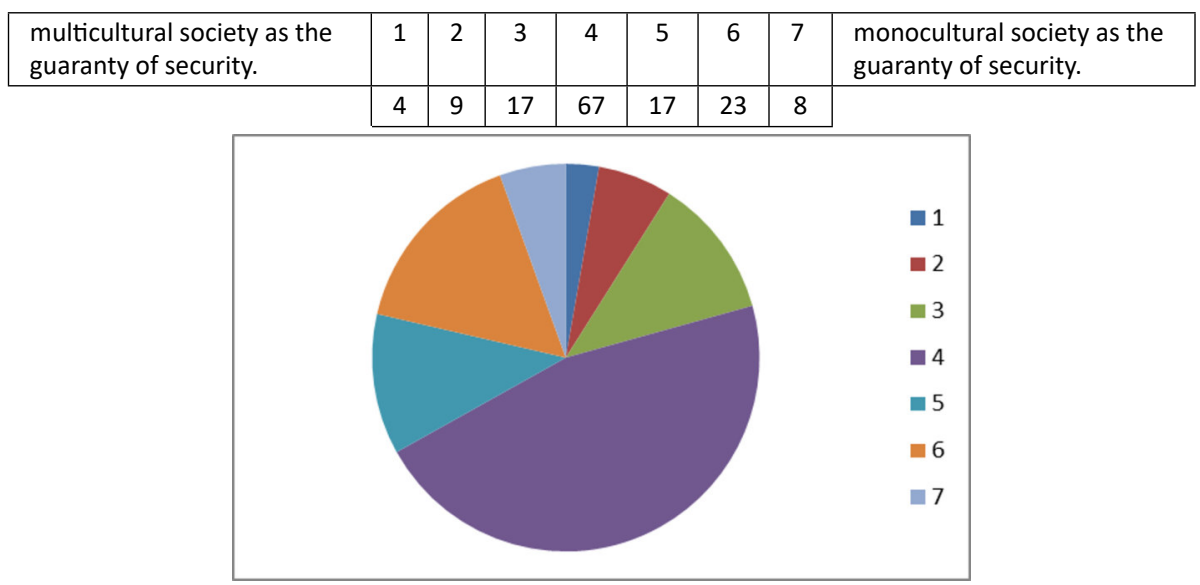

The biggest number of students (about 40\%) chose the scale position 4 in the offered spectrum, which probably means that it is difficult for them to state their opinions in this topic. Nevertheless, a bigger number of students agrees with the concept of monocultural society, which is expressed in the right side of the spectrum with the numbers 17 in the scale position 5, 23 in the scale position 6 and 8 in the scale position 7 . The left side of the spectrum is represented only by 9 answers in the scale position 2 and 4 respondents in the scale position 1.

4. Current problems in multicultural societies are related to religious radicalism of ethnic minorities and their social status. 


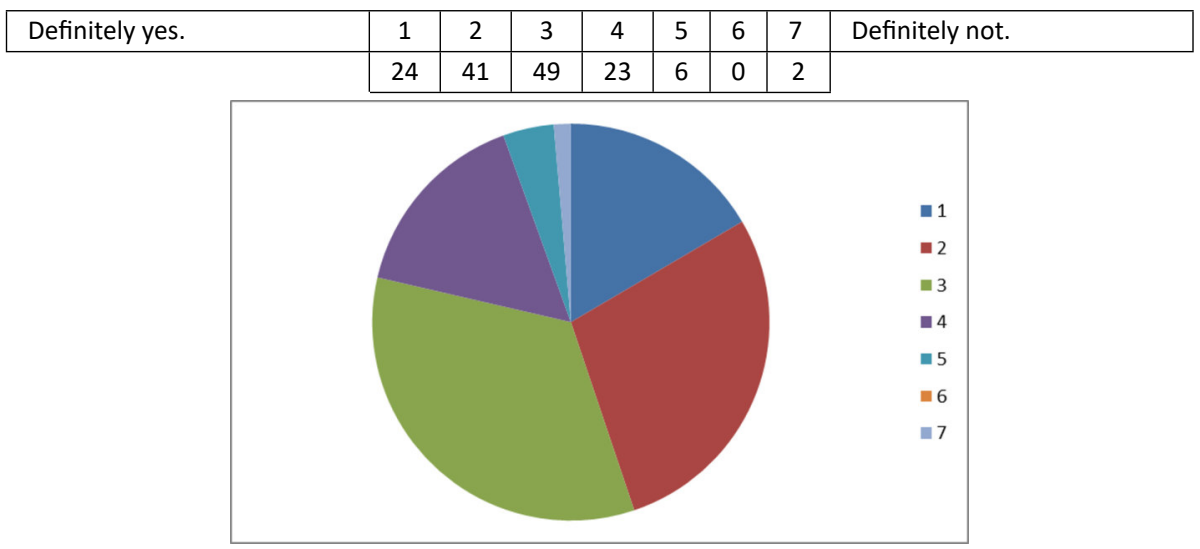

In answers to question 4 students clearly stated that religious radicalism of ethnic minorities was responsible for current problems in multicultural societies. The left side of the spectrum is distinctly dominating with the numbers 49 , which represents about $34 \%$ responses, in the scale position 3, 41 in the scale position 2 , and even with 24 in the scale position 1, which strongly supports the mentioned opinion. The right part of the scale shows very low numbers of 6 in the scale position 5,0 in the scale position 6 , and only 2 in the scale position 7 .

5. Does the education system prepare students for changing social and cultural conditions in Europe?

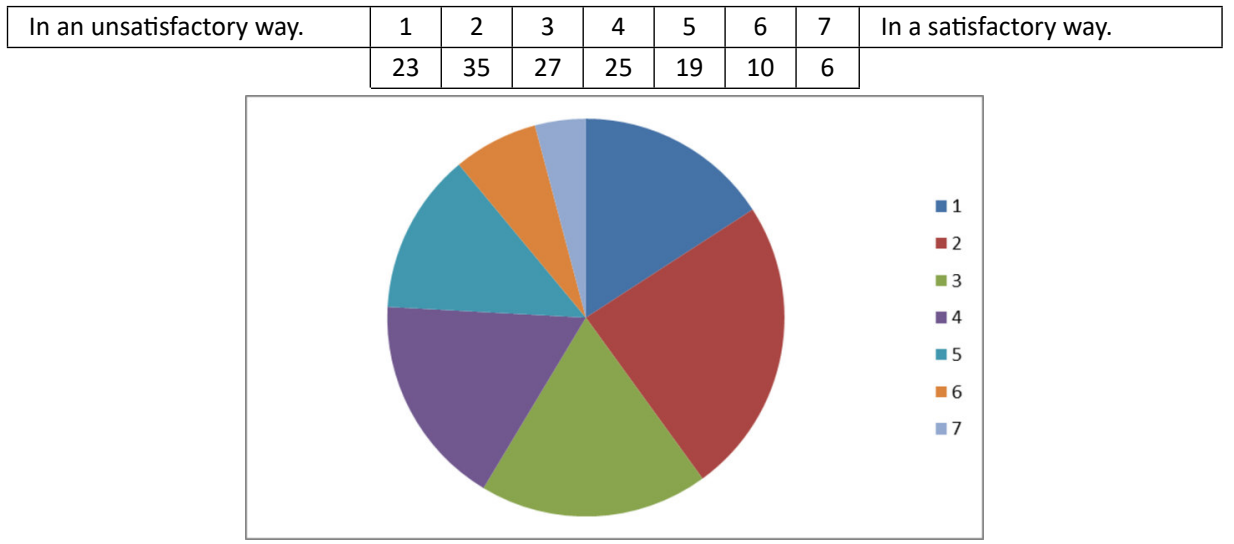

Answers to the following question 5 dealing with the preparation of the education system for changing conditions in Europe showed diversified students' opinions. The biggest number of respondents decided for the scale position 3 (27 answers) while the numbers of answers related to the scale positions 1 (23) and 2 (23) 
were relatively high. Only 6 answers appeared in the scale position 7 and there were 10 answers in the scale position 6 . It is necessary to conclude that more than half of the respondents have reservations to the education system in connection with the changing social and cultural conditions in Europe.

6. Does the education system prepare you for changing conditions on labour market in terms of cooperating with people coming from different cultural background?

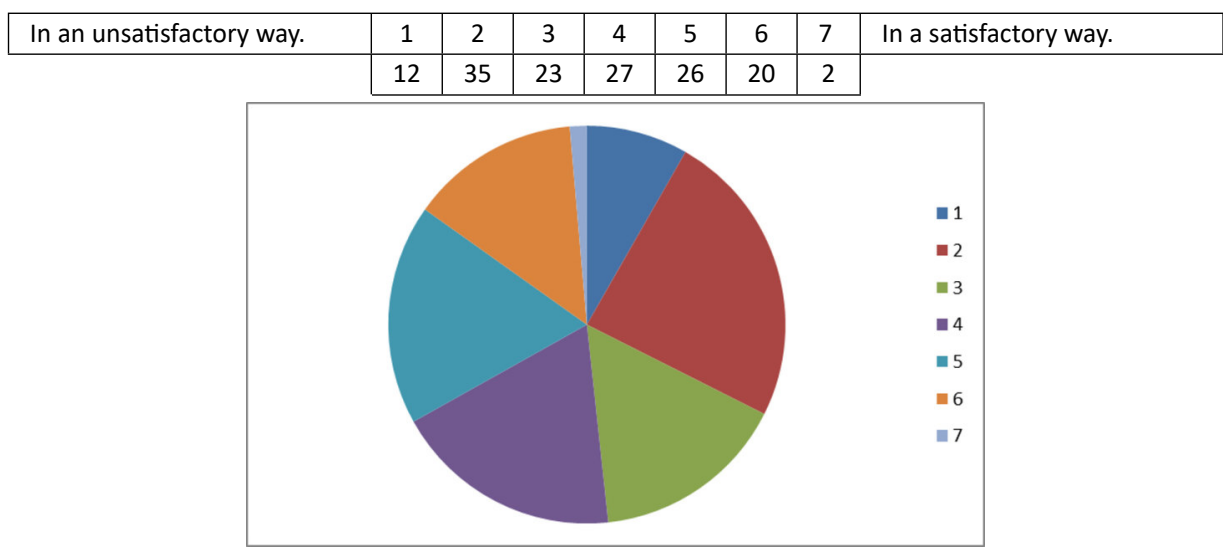

Answers to the question 6 related to the significance of political, social and cultural processes in Europe and their influence on students' future jobs proved that students were aware of the mentioned processes as students' answers were concentrated between the scale positions $2-5$, with majority of students stating not very good preparation for the new reality with the numbers 35 in the scale position 2 , and 23 in the scale position 3 , and 27 in the scale position 4 . Only one third of students chose the right side of the spectrum with the lowest number of 2 students in the scale position 7 .

7. Do you think that the current political, social and cultural processes in Europe will influence your future job? 


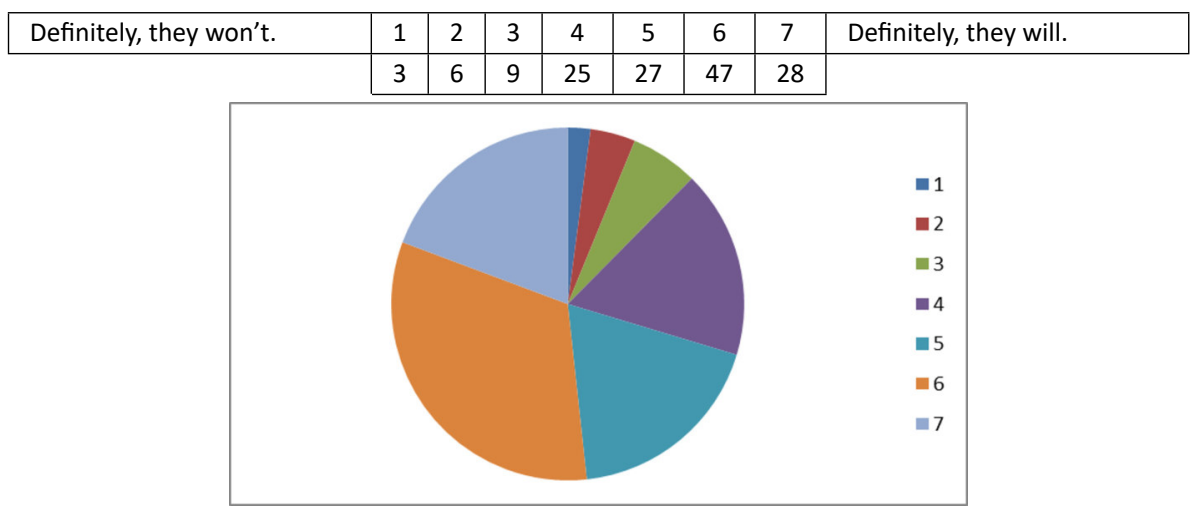

Students' answers to question 7 related to current political, social and cultural processes in Europe and their impact on their future careers were concentrated mainly in the right side of the spectrum showing the lowest numbers in the scale positions 1 to 3 . On the other hand, most answers appeared on the scale of 5 to 7 , where they reached the number 102. In the middle between the two poles, 25 and 27 responses were recorded and only a few respondents express their opinions that the current political, social and cultural processes in Europe will not influence their future jobs.

8. Do you feel to be rather

\begin{tabular}{|l|l|l|l|l|l|l|l|l|}
\hline a European citizen? & 1 & 2 & 3 & 4 & 5 & 6 & 7 & a Czech, Slovak, etc.? \\
\cline { 2 - 10 } & 2 & 8 & 5 & 20 & 27 & 35 & 58 & \multicolumn{1}{|c}{} \\
\cline { 2 - 7 } & &
\end{tabular}

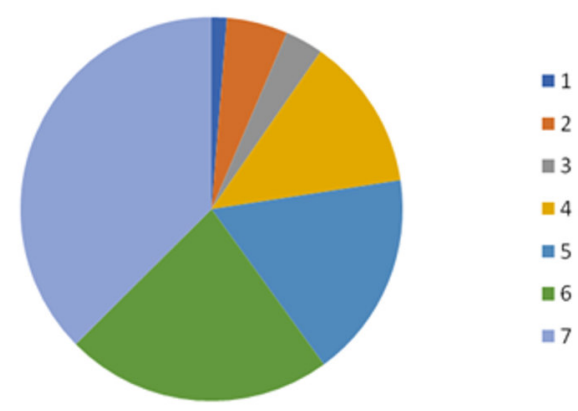

In answers to question 8, whether respondents feel more European, only two of them chose a clear answer that they felt to be Europeans. There were 15 responses in the scale positions 1 to 3. About two thirds of respondents state they feel rather to be Czechs, Slovaks, etc.) and 58 respondents clearly said that they felt more comfortable to be referred to as Czechs and Slovaks. In the middle of the scale, there were placed 20 answers. 
9. Ethnic diversity at a workplace

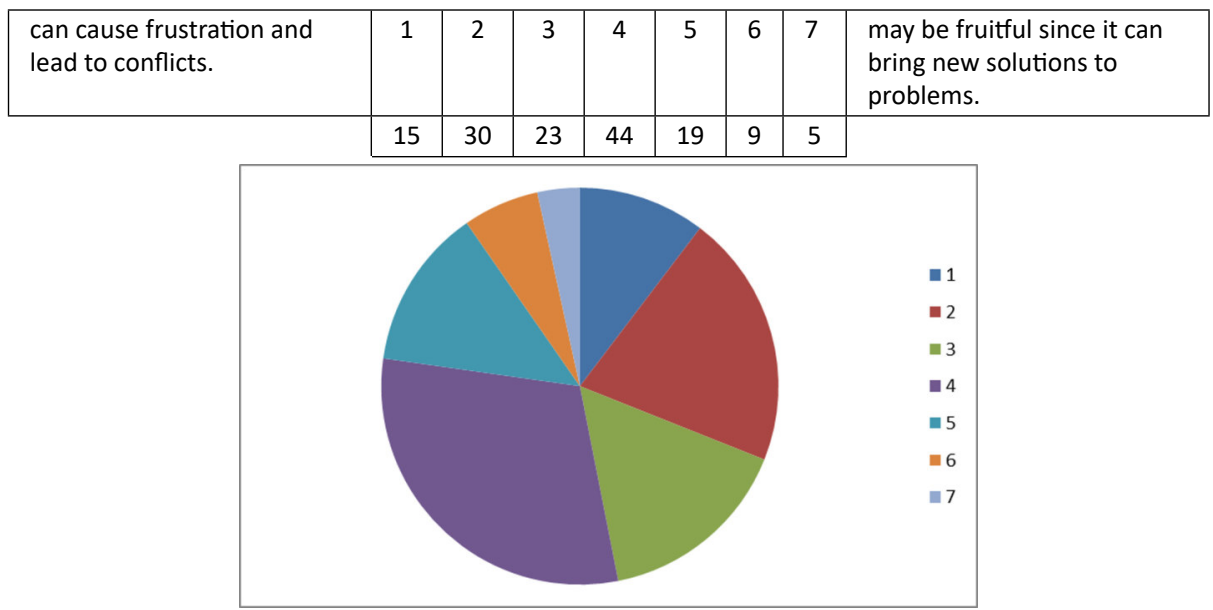

When asked about ethnic diversity in the workplace, most respondents (68) were more inclined to believe that ethnic diversity could cause frustration and conflict. 44 respondents placed their answers in the middle of the spectrum while there were 33 responses in the right side of the scale. The result seems to be surprising as majority of students cannot have many experiences with the working environment, therefore their opinions may have been influenced by stereotypes.

10. Dealing with guests of other ethnic and religious groups (e.g. Roma, Muslims, Buddhists, etc.)

\begin{tabular}{|l|l|l|l|l|l|l|l|l|}
\hline makes a job less appealing. & 1 & 2 & 3 & 4 & 5 & 6 & 7 & $\begin{array}{l}\text { makes a job more } \\
\text { interesting. }\end{array}$ \\
\hline & 17 & 20 & 30 & 36 & 24 & 13 & 5 & \\
\hline \multicolumn{10}{|r|}{} \\
\hline
\end{tabular}


The respondents commented on the issue of cooperation with members of other ethnic and religious groups (e.g. Roma, Muslims, Buddhists, etc.) in the workplace. 17 respondents believe that working with members of other ethnic and religious groups makes work less attractive. 20 respondents decided for the scale position 2, 30 respondents for the scale position 3. Only 5 respondents find work with members of other ethnic and religious groups more interesting, which gives evidence that the respondents share the common opinion existing in the society.

11. Do you feel to be prepared for the current challenges of your future profession in terms of working and dealing with individuals of other ethnic and religious groups?

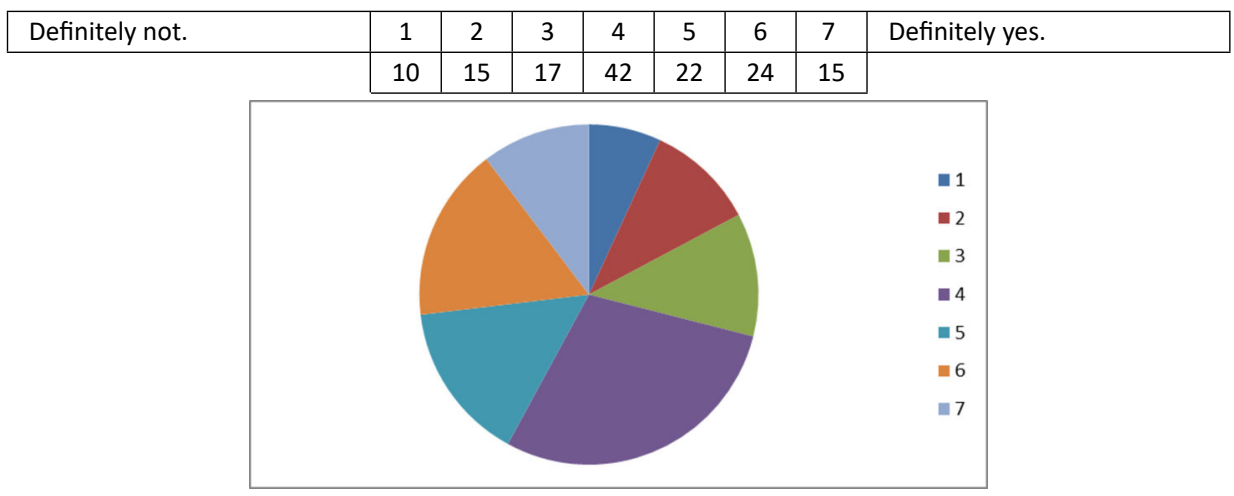

When asked whether respondents felt ready for the current challenges of working with different individuals and different ethnic and religious groups, 10 responded that they definitely did not, 15 in the opposite scale position 7 stated they definitely did. In the scale position 2 there were 15 respondents and in the scale position 3 there were 17 respondents. A total of 42 respondents placed their answers in the middle of the spectrum, but a total of 61 respondents are ready for the challenges. The presented answers may indicate that the respondents have already attended courses related to intercultural communication including topics as cultural values, acculturation, overcoming stereotypes and prejudice, etc.

\section{Discussion}

The following discussion will summarize the presented results and compare them to selected questions from a similar survey conducted at the beginning of the summer term 2015/2016 among 149 respondents.

Answering the questions in the first half of the questionnaire, respondents have shown awareness related to current economic, social, and religion phenomena occurring in the society. However, they are not able to state clearly, whether the 
ethnic diversity presents danger or enrichment in various aspects of life. Although, on the other hand, they expressed their opinions that compassion and tolerance with other ethnic groups were significant for them. They tend to perceive monocultural society as a guaranty of security and in their views the problems related to radicalism of ethnic minorities are responsible for current problems in multicultural societies. As far as education system is concerned, more than half of the respondents have reservations to the education system in connection with the changing social and cultural conditions in Europe and majority of students state not very good preparedness for the new reality.

In most of the answers related to the second half of the questionnaire, respondents were convinced that their future careers would be influenced by the current political, social and cultural processes in Europe. When evaluating the question whether respondents feel more Europeans or Czechs, Slovaks, etc., they showed greater belonging to the concept of "national" rather than "European." It was clear that a kind of tension occurred between the "national" and the "global". The global phenomenon seems to be overshadowed by the national phenomenon. In terms of ethnic diversity, the global phenomenon again encountered the phenomenon of the national identity. The results of the survey showed that respondents were more inclined to believe that ethnic diversity in the workplace could cause frustration and conflict, as their answers were on this side of the scale. Therefore, it could not be shown that ethnic diversity in the workplace was considered beneficial for respondents at the time of the research. Therefore, there has been some sort of hesitancy, or unconvinced and indecisive attitude to the view of the benefits of ethnic diversity in the workplace, or that ethnic diversity in the workplace can lead to conflict. Also, questions related to the fact whether respondents feel ready for the current challenges of working with different individuals and different ethnic and religious groups showed that they were not convinced that they would be prepared or unprepared to work with people from different cultures and religious preferences.

The above listed findings can be compared to a similar survey conducted at the beginning of the summer term 2015/2016 among 149 (a similar number of respondents to the current survey) students of School of Business Administration in Karviná, Silesian University in Opava, but only 7 questions of the mentioned questionnaire were identical with the current survey.

In the answers to question 1 about students' attitudes to cultural and religious diversity, the situation was similar to the current one as majority of answers were placed in the middle of the scale within the scale positions 3-5.

In the responses related to questions 2 about compassion and tolerance students in the previous survey stated that compassion and tolerance were very important for them, which corresponds with the results of the current research. 
Question 3 about monocultural and multicultural society was answered in the similar way as in the previous research with a slightly more respondents stating that a monocultural society is the only guarantee of security.

Answers to question 4 in both surveys clearly state that religious radicalism of ethnic minorities is responsible for current problems in multicultural societies with the left side of the spectrum distinctly dominating.

Question 5 focused on the preparedness of the education system for changing conditions on labour market showing students' diversified opinions with the inclination towards the left side of the spectrum, which indicates the fact that in both cases respondents have strong reservations to the education system in connection with the changing social and cultural conditions in Europe.

Responses to question 6 also show similar results. Students in both surveys declare that preparedness of the education system for changing conditions on labour market showed diversified students' opinions but with reservations to the education system in connection with the changing conditions on labour market.

Question number 7 was aimed at the problem of the national identity (Czechs, Slovaks, Europeans, etc.) where in both surveys majority of students are convinced that they rather belong to the Czech or Slovak nation than to the Europeans.

Concluding the comparison of two mentioned surveys, it is possible to state that the answers in the selected comparable 7 questions of the questionnaire have proved that students' responses in both surveys show similar trends, i.e. they are almost identical with the exception of question 3 where students presented a more radical opinion related to the danger connected with multicultural societies indicating a shift in attitudes.

\section{Conclusion}

Cultural diversity determines today's globalizing societies from different perspectives, including employers' needs, preparedness of school leavers, the broader demographic context in terms of employability and the labour market, management and human resources development, sustainable education, etc. which should be addressed in further research surveys.

After the evaluation of the questionnaire survey, it can be stated that the respondents were not able to state clear answers to some questions, probably due to the shortage of experience in the area. Therefore, for example they hesitated whether ethnic diversity presented danger or enrichment in various aspects of life, but at the same time, they expressed their opinions that compassion and tolerance with other ethnic groups were important for them. 
The results of the survey showed that respondents were more inclined to believe that ethnic diversity in the workplace could cause frustration and conflict and they preferred to be referred to as Czech and Slovaks rather than the European citizens.

As far as the education system is concerned, more than half of the respondents have reservations to the education system in connection with the changing social and cultural conditions in Europe and labour market.

The article also involved a short comparison of selected responses in the surveys conducted in 2016 and 2020. The results show very similar trends, only students' opinions related to multicultural societies in 2020 present a more radical opinion related to the danger connected with them.

In our research we wanted to point out that the increasing global heterogeneity in societies posed many challenges for the national community and the globalizing world, education being one of them. The readiness of the education system to meet the challenges of the 21st century is one of the priorities that should be reflected in the university curricula so that university graduates are prepared for today's world. The presented survey is planned to be continued in the future by comparison of Czech and Slovak students' attitudes at two tertiary education institutions.

\section{Literature}

Apeltaufer, E. (1996). Körpersprache in der interkulturellen Kommunikation. In Flensburger Papiere zur Mehrsprachigkeit und Kulturvielfalt im Unterricht. Flensburg: Universität Flensburg.

BADE, K. (2015). Kulturvielfalt, Kulturangst und negative Integration in der Einwanderungsgesellschaft. In KazzAzI, K., Treiber, A., \& WäTzold, T. Migration-Religion-Identität. Aspekte transkultureller Prozesse, 1-34.

BADE, K. J. (2016). Prolog Kulturvielfalt, Kulturangst und Negative Integration in der Einwanderungsgesellschaft. In Migration-Religion-Identität. Aspekte transkultureller Prozesse (1-34). Wiesbaden: Springer VS.

DiAs, P. V. (1991). Grenzen des idealtypischen Vergleichs in der Erziehungswissenschaft im Rahmen internationaler Marktstrukturen und Kulturvielfalt. Interkulturelles Lernen oder verdeckte Dominanz, Frankfurt a. M.: Verlag für Interkulturelle Kommunikation, 31-54.

Engel, D., \& Colombo, S. (2018). Strategien in der Förderung von Multilingual Awareness im Rahmen der Südtiroler Wanderausstellung "Sprachenvielfalt - in der Welt und vor unserer Haustür". Strategien im Kontext des mehrsprachigen und lebenslangen Lernen, 6, 101.

FelcmanovÁ, A. (2018). Sociokulturní diverzita organizací ve vzdělávání. Sociální pedagogika/ Social Education, 6(1), 28-46.

Heuser, S., Spürk, D., Walter, A., Zanier, G., Koch, E., Staudt, J., ... \& Bauermann, E. (2019).

Transkulturelle Pflege: Grundlagen und Praxis. Stuttgart: Kohlhammer Verlag.

SEIPP, B. (2007). Sprache fördern - Kulturvielfalt erleben: Lehrerausbildung praxisnah. Dortmund: Zentrum für Lehrerausbildung.

KazzAzI, K., Treiber, A., \& WäTzold, T. (2016). Migration, Religion, Identität: Aspekte transkultureller Prozesse. Wiesbaden: Springer VS. 
KenNER, M. (2006). Zur moralischen Dimension in der interkulturellen Begegnung. In Bedingungen beruflicher Moralentwicklung und beruflichen Lernens. Wiesbaden: VS Verlag für Sozialwissenschaften, 49-61.

LARSEN-FrEemAN, D. (2012). From Unity to Diversity. In: English Teaching Forum. 50(2), Washington: Office of English Language Programs. 22-27.

MASCHwitz, A. (2018). Kooperationen mit Wirtschaftsunternehmen in der Weiterbildung Unternehmerische Kultur als Chance und Herausforderung. In Nachhaltigkeit in der wissenschaftlichen Weiterbildung. Springer VS, Wiesbaden, 2018. 253-269.

MäDER, O. B. (2018). Der Objektivierungsprozess. In Controlling klipp \& klar. Springer Gabler, Wiesbaden, 63-94.

Mense-Petermann, U. (2006). Kulturvielfalt als Steuerungsproblem - zur Rolle von Anerkennung als Steuerungsressource in transnationalen Konzernen. In Kongress der Deutschen Gesellschaft für Soziologie "Soziale Ungleichheit - kulturelle Unterschiede". Campus Verlag, 2006. 1499-1510.

PAufler, A. (2019). Denkstrategie: Integrationsdenken. In Führung-Kreativität-Innovation. Wiesbaden: Springer Gabler, 127-155.

SснÜтTE, U. (2016). Kommunikativer interkultureller Kompetenzerwerb in der "Fremde" - Ein Muss für die sprachtherapeutische Professionalisierung in Zeiten der Globalisierung? Eine qualitative Analyse interkultureller Erfahrungen. In HEDDERICH, I., \& ZAHND, R. (EDS.): Teilhabe und Vielfalt: Herausforderungen einer Weltgesellschaft. Beiträge zur internationalen Heil- und Sonderpädagogik. Bad Heilbrunn: Verlag Julius Klinkhardt, 208-214.

SchÜTTE, U. (2018). Beiträge zur sprachpädagogischen und sprachtherapeutischen Professionalisierung. In Das Fremde im Kontext sprachlich-kultureller Diversität. Wiesbaden: Springer VS, 97-205.

TAKAHASHI, H., BAN, M., \& ASADA, M. (2016). Semantic Differential Scale Method Can Reveal Multi-Dimensional Aspects of Mind Perception. Frontiers in psychology, 7(1717).

URBANovÁ, H., ČERMÁKovÁ, H., \& VostrovsKÁ, H. (2016). Diversity management. Acta Universitatis Agriculturae et Silviculturae Mendelianae Brunensis, 64 (3).

VAŠŤ́́TKová, J., \& CHVAL, M. (2018). Využití sémantického diferenciálu při autoevaluaci školy. Orbis Scholae 4 (1), 111-128.

\section{Authors}

PhDr. Krystyna Heinz, School of Business Administration in Karviná, Silesian University in Opava, e-mail: heinzova@opf.slu.cz

She teaches at School of Business Administration in Karviná, Silesian University in Opava, Business English and courses related to Intercultural Communication designed for students of the Erasmus Programme and other international students, for example Culture Values in Business Communication, Personal Development Course for Mobility, Preparatory Course for Student Mobility, Introduction to the Czech Language and Cultures, etc. She has been involved in several international projects focusing on developing intercultural competence in multicultural groups of students, the last one being the project ECMT in cooperation with 6 European universities in Belgium, Germany, Finland, France, Poland, Scotland - Entrepreneurial Communication in Multicultural Teams.

PhDr. Hanne-Lore Bobáková, Ph.D., School of Business Administration in Karviná, Silesian University in Opava, e-mail: bobakova@opf.slu.cz

She teaches at School of Business Administration in Karviná, Silesian University in Opava, Business German and courses related to Communication in Czech Language and Intercultural Communication designed for faculty students and students of the University of the Third Age, for example topics such as Argumentation, Persuasion, Cultural Diversity for the needs of international trade, etc. She has participated in faculty projects aimed at optimizing teaching of German Language, Communication Skills in Tourism and Crisis Communication. 